\title{
Identification and description of distinct B chromosomes in Cyphocharax modestus (Characiformes, Curimatidae)
}

\author{
Lessandra Viviane De Rosa Santos ${ }^{1}$, Fausto Foresti ${ }^{1}$, Cesar Martins ${ }^{1}$, Claudio Oliveira ${ }^{1}$ \\ and Adriane Pinto Wasko ${ }^{2}$ \\ ${ }^{I}$ Departamento de Morfologia, Instituto de Biociências, Universidade Estadual Paulista, Botucatu, \\ SP, Brazil. \\ ${ }^{2}$ Departamento de Genética, Instituto de Biociências, Universidade Estadual Paulista, Botucatu, SP, Brazil.
}

\begin{abstract}
Cytogenetic analyses were performed in Cyphocharax modestus, collected at Paranapanema River and Tietê River (São Paulo State, Brazil). A karyotype with $2 n=54$ chromosomes was observed in the animals from both Brazilian freshwater river systems. One to four B chromosomes were also detected in individuals from the Paranapanema River, which represents the probable first report of more than a single supernumerary element in a species of the Curimatidae group. C-banding revealed centromeric and telomeric heterochromatin blocks in several chromosomes of the normal karyotype complement of $C$. modestus. Moreover, while some $B$ chromosomes were characterized by the complete absence of $\mathrm{C}$-bands, others were totally heterochromatic. Although there was a prevalence of $\mathrm{B}$ chromosomes in males of $C$. modestus, at least one supernumerary element was found in males and/or females of several other populations of the species, which suggests that the presence of these chromosomes seems to represent a general trait of $C$. modestus. A possible origin of the described $B$ chromosomes may be related to the occurrence of a chromosome non-disjunction followed by the loss of euchromatic segments, an event that should have occurred in chromosomes that present conspicuous centromeric heterochromatic blocks and even in chromosomes that lack C-bands in this region, resulting in small supernumerary elements.
\end{abstract}

Key words: B chromosomes, C-banding, Curimatidae, Cyphocharax modestus, supernumerary chromosomes.

Received: August 18, 2006; Accepted: May 14, 2007.

In addition to the standard chromosome complement, B chromosomes, also known as supernumerary or accessory elements, can be found in several animal and plant species (Jones, 1975). As fish represent one of the most numerous and diverse vertebrate groups, comprising species that can be found in almost all aquatic environments (Nelson, 1994), it is expected that different species could present B chromosomes. The occurrence of extra chromosomes has been reported in individuals and populations of different fish groups as Characiformes, Siluriformes, Perciformes, Beloniformes, and Synbranchiformes, representing approximately $5 \%$ of all Neotropical freshwater fish already cytogenetically studied (C. Oliveira, personal communication).

The Neotropical members of the order Characiformes present a wide chromosome diversity characterized by the occurrence of stable karyotype groups as well as divergent ones (Bertollo et al., 1986). The Curimatidae family can be

Send correspondence to Adriane Pinto Wasko. Departamento de Genética, Instituto de Biociências, Universidade Estadual Paulista, 18618-000 Botucatu, SP, Brazil. E-mail: awasko@ ibb.unesp.br. included in the first group (Galetti et al., 1994) since most studied species present a diploid number of 54 chromosomes and the karyotype composed by metacentric and submetacentric elements (Scheel, 1973; Galetti et al., 1981, Galetti et al., 1991; Pauls and Bertollo, 1990; Feldberg et al., 1992; Navarrete and Julio, 1997). Despite its macro-structural karyotype stability, the occurrence of B chromosomes has been described in some curimatids, such as Cyphocharax modestus (Venere and Galetti, 1985; Martins et al., 1996), Steindachnerina insculpta (Oliveira and Foresti, 1993), and Cyphocharax spilotus (Fenocchio et al., 2003).

The aim of the present study was to verify the occurrence of supernumerary chromosomes in Cyphocharax modestus from the Paranapanema and Tietê Rivers in order to compare the results with those obtained for other populations of the species.

Samples of Cyphocharax modestus Fernándes-Yépes 1948 were collected at Paranapanema River (Jurumirim Hydroelectric Reservoir, border municipality of Paranapanema and Angatuba, São Paulo State, Brazil), represent- 
ing twenty males and nine females, and at Tietê River (municipality of Botucatu, São Paulo State, Brazil), representing three males and nine females.Mitotic chromosomes were obtained from kidney cells, as described by Foresti et al. (1993). Detection of constitutive heterochromatin (Cbanding) was performed as described by Sumner (1972), with some minor modifications. The analyzed animals were deposited at the museum of the Laboratório de Biologia e Genética de Peixes, Instituto de Biociências, UNESP, Botucatu, SP, Brazil.

All analyzed individuals of $C$. modestus from Paranapanema and Tietê Rivers had a karyotype with a diploid number of $2 n=54$, consisting exclusively of metacentric and submetacentric chromosomes (De Rosa et al., in press). Although no differences were observed in the normal karyotype complement of $C$. modestus from the two collecting sites, one to four small supernumerary chromosomes could be evidenced only in individuals of this species collected at the Paranapanema River (Figure 1 and Tables 1 and 2). The identification of a high number of individuals with only one supernumerary chromosome may be related to the reduced number of analyzed animals. How- ever, we could not discard the possibility that the presence of more than a single extra element in the organism of this fish species can be related to a deleterious effect.

The occurrence of a supernumerary chromosome was previously detected in different Curimatidae species, such as C. modestus from the Tietê River (Venere and Galetti, 1985), Piracicaba River (Venere et al., 1999), and Tibagi River (Martins et al., 1996), Steindachnerina insculpta from the Paranapanema River (Oliveira and Foresti, 1993), and Cyphocharax spilotus from the Paraná-Plata basin (Fenocchio et al., 2003; Brassesco et al. 2004). The presence of more than one B chromosome in Curimatidae, as ob-

Table 1 - B chromosome distribution in Cyphocharax modestus from the Paranapanema River.

\begin{tabular}{lcc}
\hline Number of B chromosomes & males & females \\
\hline 0 & 12 & 8 \\
1 & 4 & 1 \\
2 & 2 & - \\
3 & 1 & - \\
4 & 1 & - \\
\hline
\end{tabular}
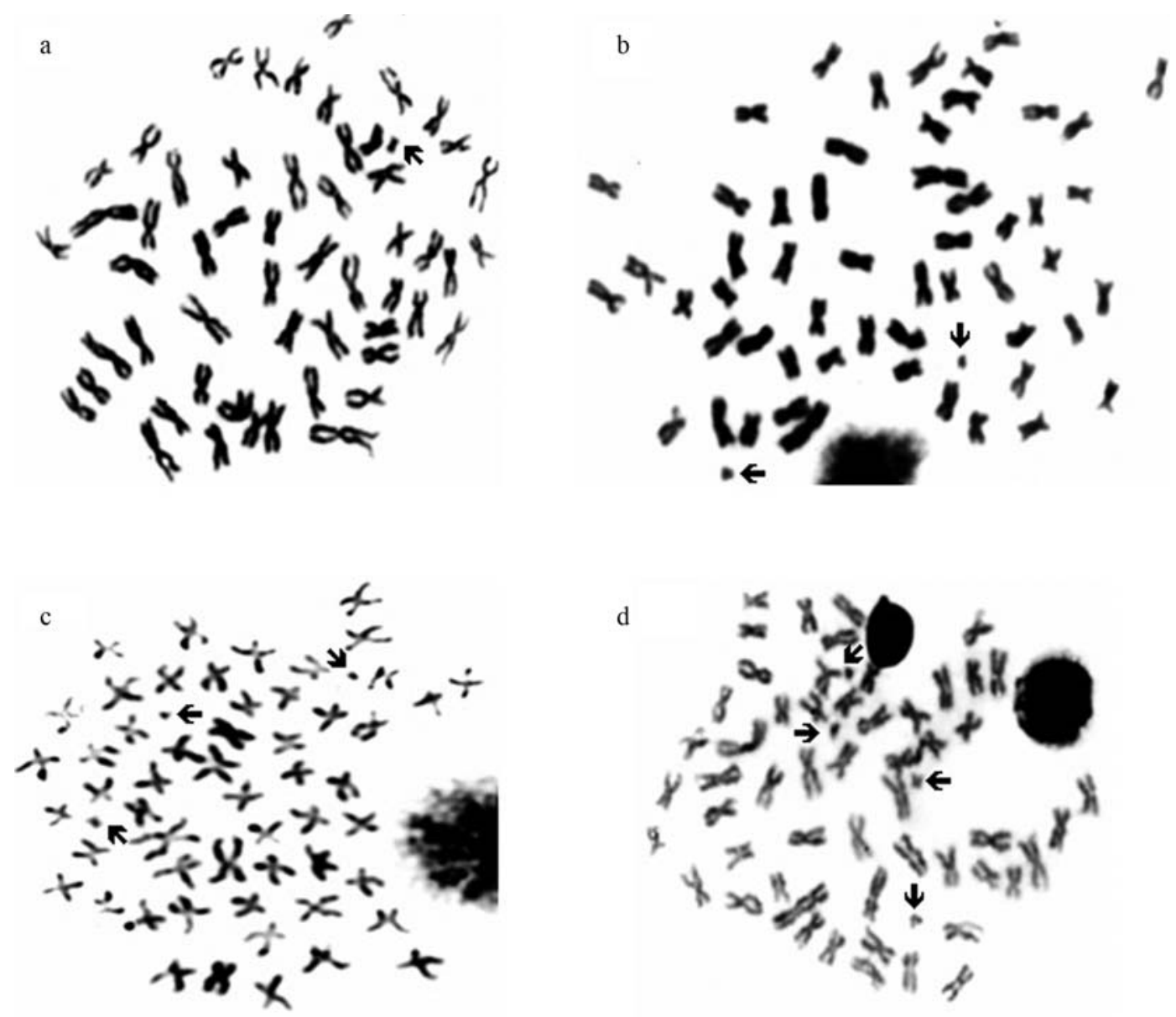

Figure 1 - Giemsa-stained metaphases of Cyphocharax modestus from the Paranapanema River evidencing (a) one supernumerary chromosome, (b) two supernumerary chromosomes, (c) three supernumerary chromosomes, and (d) four supernumerary chromosomes. 
Table 2 - Distribution of B chromosomes in specimens of Cyphocharax modestus from the Paranapanema River.

\begin{tabular}{|c|c|c|c|c|c|c|c|c|c|}
\hline Specimen identification & Sex & $2 n+B s$ & 0 & 1 & 2 & 3 & 4 & B cell frequency $(\%)$ & Total number of cells \\
\hline 12211 & male & $54+1$ & 2 & 17 & - & - & - & 0.89 & 19 \\
\hline 12215 & male & $54+1$ & 3 & 23 & - & - & - & 0.88 & 26 \\
\hline 12232 & male & $54+1$ & 4 & 23 & - & - & - & 0.85 & 27 \\
\hline 12235 & male & $54+4$ & - & 1 & - & - & 31 & 1 & 32 \\
\hline 12412 & male & $54+2$ & - & 2 & 16 & - & - & 1 & 18 \\
\hline 13604 & male & $54+1$ & 2 & 13 & - & - & - & 0.86 & 15 \\
\hline 13627 & female & $54+1$ & - & 24 & - & - & - & 1 & 24 \\
\hline 13797 & male & $54+2$ & - & 6 & 36 & - & - & 1 & 42 \\
\hline 13643 & male & $54+3$ & 2 & - & - & 15 & - & 0.88 & 17 \\
\hline
\end{tabular}

served in the present study in $C$. modestus from the Paranapanema River system, appears to constitute an uncommon feature for this fish group.

Many supernumerary chromosomes bear active gene cistrons, as found in some amphibian species (e.g. Green, 1990). However, previous data using Ag-staining and 18S rDNA-FISH showed that the Nucleolar Organizer Regions (NORs) were localized in a single chromosome pair of the normal karyotype complement of the species and no ribosomal cistrons could be associated with the B elements of C. modestus from the Paranapanema River (De Rosa et al., in press), confirming other previous data on individuals of C. modestus captured in other freshwater systems which also presented B chromosomes (Venere and Galetti, 1985; Venere, 1991; Martins et al., 1996). FISH experiments also revealed that $5 \mathrm{~S}$ rDNA cistrons are not present in the supernumerary chromosomes of the species (De Rosa et al., 2006).

Heterochromatic B chromosomes represent a common feature in several fish species, as observed in Prochilodus scrofa (Pauls and Bertollo, 1983), Pimelodella kronei (Almeida-Toledo and Foresti, 1985), Rhamdia sp. (Hochberg et al., 1985), Corydoras aeneus (Oliveira et al., 1988), Leporinus friderici, Leporinus sp. and Prochilodus nigricans (Venere et al., 1999) among others. However, some cases of euchromatic supernumerary chromosomes, after C-banding treatments, have also been described in fish, such as Moenkhausia sanctaefilomenae (Foresti et al., 1989), and Characidium cf. zebra (Venere et al., 1999).

$\mathrm{C}$-banding revealed centromeric and telomeric heterochromatin blocks in several chromosomes of the normal complement of $C$. modestus from the Paranapanema River (De Rosa et al., in press). Moreover, while some B chromosomes of this species were characterized by the complete absence of C-bands, other supernumerary elements were totally heterochromatic (Figure 2). The supernumerary chromosomes found in individuals with just one of these elements were always entire heterochromatic. However, heterochromatic and euchromatic supernumerary chromosomes could be identified in animals bearing two or more of these chromosomes. Whereas Venere and
Galetti (1985) found a single B chromosome in C. modesta in a sample from the Tietê River system that was fully heterochromatic, a euchromatic supernumerary chromosome was described in Steindachnerina insculpta (Oliveira and Foresti, 1993). Although the occurrence of both totally heterochromatic or euchromatic B chromosomes in the same individual has been described in other fish species, such as Moenkhausia sanctaefilomenae (Foresti et al., 1989), the occurrence in C. modestus from the Paranapanema River seems to be the first report for Curimatidae.

It has been proposed that the presence of B chromosomes could be related to ecological factors. In fish species, autosomal breaks due to water pollutants could lead to the occurrence of B elements, as suggested for Charax leticiae (Miyazawa and Mondin-Freitas, 2004) and Sphoeroides greeley (Alves et al., 2002). The present identification of B chromosomes in several individuals of $C$. modestus from the Paranapenema River and their absence in samples from the Tietê River also could suggest a correlation between B chromosomes and different environmental conditions in these two hydrographic regions. However, as Venere and Galetti (1985) had already found a B chromosome in some individuals of $C$. modestus from the Tietê River system, and considering that a restricted number of individuals from this region were analyzed, we could not discard that the population differences may be due to small sampling size.

Although we have analyzed a larger number of males than females, it seems that the frequency of the B chromosomes is higher in males than in females (Table 1). This contrasts with findings by Martins et al. (1996) who identified a B chromosome only in females of C. modestus. Supernumerary chromosomes associated with a given sex have been described in some fish species such as Astyanax scabripinnis (Stange and Almeida-Toledo, 1993), and Astyanax scabripinnis paranae (Maistro et al., 1992). The presence of a B chromosome in different percentages between sexes could be related to deleterious effects in one of the sexes, leading to its partial or total non-viability or, could be related to the occurrence of sex-determining genes in these chromosomes (Green, 1990). 

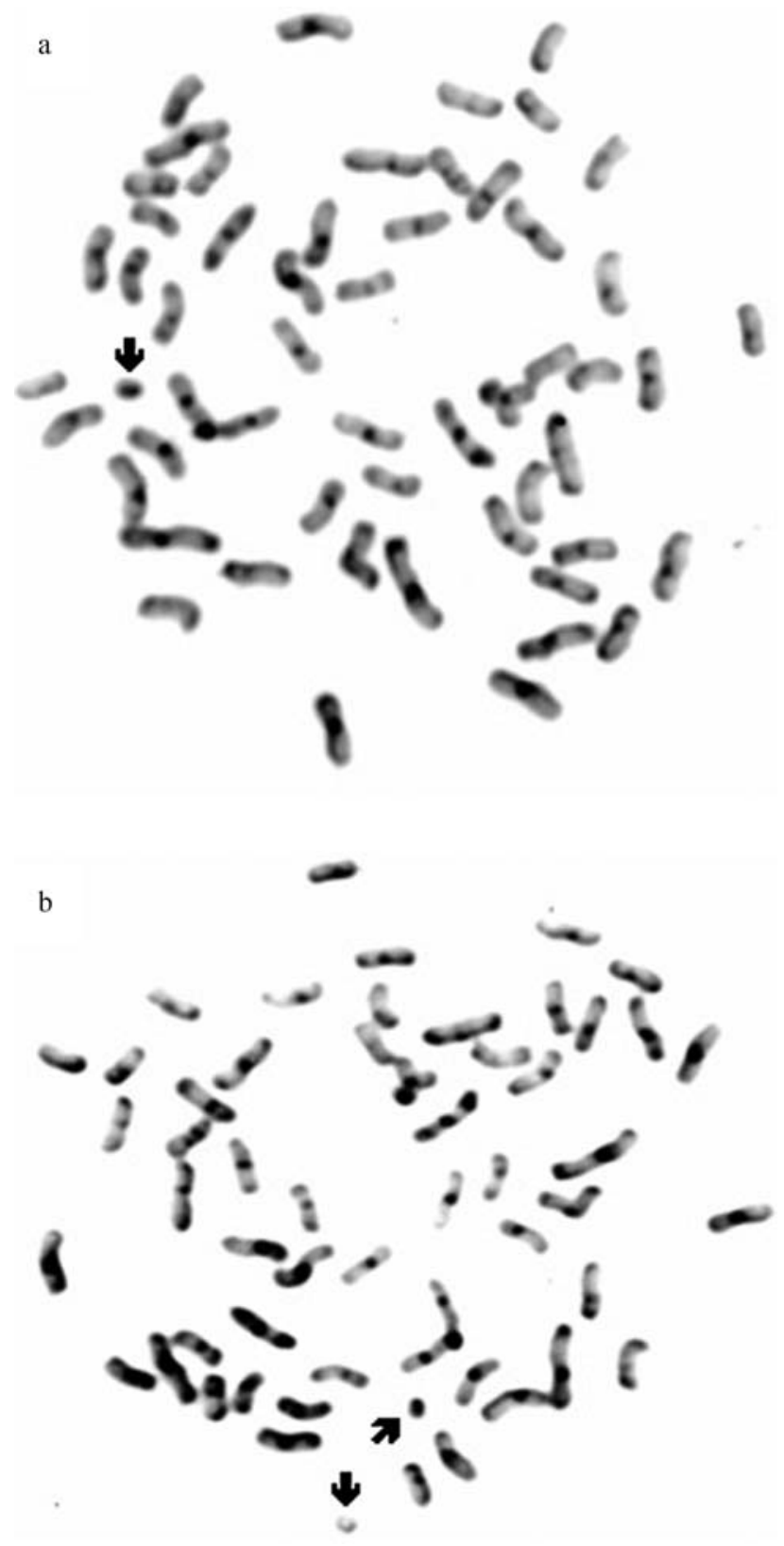

Figure 2 - C-banding metaphases of Cyphocharax modestus from the Paranapanema River, evidencing (a) a heterochromatic supernumerary chromosome, (b) euchromatic and heterochromatic supernumerary chromosomes.

Cytogenetic data compilation on C. modestus revealed that small B chromosomes were identified in females and/or males and in samples from several populations of the species - Tietê River (Venere and Galetti, 1985), Piracicaba River (Venere and Galetti, 1989), Tibagi River (Martins et al., 1996), and Paranapanema River (present data). Theses facts suggest that at least one B chromosome could represent a general trait of C. modestus and its widespread distribution is probably due to the high mobility of this species.

Moreover, another Curimatidae species, such as Steindachnerina insculpta and Cyphocharax spilotus, also had a B chromosome (Oliveira and Foresti, 1993; Fenocchio et al., 2003). Therefore, supernumerary elements could have arisen in an ancestor of this fish family and were eliminated from the present species that do not bear B chromosomes. Alternatively, they could have had a recent and independent origin in the family. A possible origin of the two kinds of B chromosomes now described may be related to the occurrence of a chromosome non-disjunction, followed by the loss of euchromatic segments. If so, this event should have occurred in chromosomes presenting conspicuous centromeric heterochromatic blocks and even in chromosomes with the lack of C-bands in this region, resulting in small heterochromatic and euchromatic B chromosomes, respectively.

\section{Acknowledgments}

L.V.R.S. was supported by a fellowship from Coordenação de Aperfeiçoamento de Pessoal de Nível Superior (CAPES). This work was also supported by grants from Conselho Nacional de Desenvolvimento Científico e Tecnológico (CNPq), and Fundação de Amparo à Pesquisa do Estado de São Paulo (FAPESP).

\section{References}

Almeida-Toledo LF and Foresti F (1985) As regiões organizadoras de nucléolos em peixes. Ciência e Cultura 37:448-453.

Alves AL, Porto-Foresti F, Oliveira C and Foresti F (2002) Ocorrência de cromossomo B no baiacu marinho Sphoeroides greeleyi (Tetrodontiformes, Tetraodontidae). IX Simpósio de Citogenética e Genética de Peixes, Maringá, Brazil, 113 pp.

Bertollo LAC, Moreira Filho O and Galetti PM (1986) Cytogenetics and taxonomy: Considerations based on chromosome studies of freshwater fish. J Fish Biol 28:153-160.

Brassesco MS, Pastori MC, Roncati HA and Fenocchio AS (2004) Comparative cytogenetic studies of Curimatidae (Pisces, Characiformes) from the middle Paraná River (Argentina). Genet Mol Res 3:293-301.

De Rosa LVS, Foresti F, Martins C, Oliveira C and Wasko AP (2007) Cytogenetic analyses of two Curimatidae species (Pisces, Characiformes) from the Paranapanema and Tietê Rivers. Braz J Biol 67: 333-338.

De Rosa LVS, Foresti F, Wasko AP, Oliveira C and Martins C (2006) Nucleotide sequence, genome organization and chromosome localization of 5S rDNA in two species of Curimatidae (Pisces, Characiformes). Genet Mol Biol 29:251256.

Feldberg E, Porto JIR and Bertollo LAC (1992) Karyotype evolution in Curimatidae (Teleostei, Characiformes) of the Amazon region. 1. Studies on the genera Curimata, Psectrogaster, Steindachnerina and Curimatella. Rev Bras Genet 15:369-383.

Fenocchio AS, Pastori MC, Roncati HA, Moreira Filho O and Bertollo LAC (2003) A cytogenetic survey of the fish fauna from Argentina. Caryologia 2:197-204.

Foresti F, Almeida-Toledo LF and Toledo-Filho SA (1989) Supranumerary chromosomes systems, C-banding pattern characterization and multiple nucleolus organizer regions in 
Moenkhausia sactaefilomenae (Pisces, Characidae). Genetica 79:107-114.

Foresti F, Oliveira C and Almeida Toledo LF (1993) A method for chromosome preparations from large specimens of fishes using in vitro short treatment with colchicine. Experientia 49:810-813.

Galetti PM, Foresti F, Bertollo LAC and Moreira Filho O (1981). Karyotypic similarity in three genera (Leporinus, Leporellus and Schizodon) of the family Anostomidae (Pisces, Teleostei). Rev Bras Genet 4:11-15.

Galetti PM, Cesar ACG and Venere PC (1991) Heterochromatin and NORs variability in Leporinus fish (Anostomidae, Characiformes). Caryologia 44:287-292.

Galetti PM, Bertollo LAC and Moreira Filho O (1994) Trends in chromosome evolution of Neotropical characiform fishes. Caryologia 47:289-298.

Green DM (1990) The chromosomes in some lower Chordata. Chomosoma 21:181-188.

Hochberg VBM, Erdtmann B and Leistner S (1985) Caracterização de cromossomo supranumerario ou $\mathrm{B}$ em Jundiás (Pisces, Pimelodidae). Ciência e Cultura 37:733.

Jones RN (1975) B-chromosome systems in flowering plants and animal species. Internat Rev Cytol 40:1-100.

Maistro EL, Foresti F, Oliveira C and Almeida-Toledo LF (1992) Occurrence of macro B chromosome in Astyanax scabripinnis paranae (Pisces, Characiformes, Characidae). Genetica 87:101-106.

Martins C, Giuliano-Caetano L and Dias AL (1996) Occurrence of a B chromosome in Cyphocharax modesta (Pisces, Curimatidae). Cytobios 85:247-253.

Miyazawa C and Mondim-Freitas PD (2004) Presença de microcromossomos em Charax leticiae (Characidae, Characinae) do rio Piranema, MT. XXVII Seminário de Estudos Biológicos, Cuiabá, Brazil.
Navarrete MC and Júlio HF (1997) Cytogenetic analysis of four Curimatidae from the Paraguay basin, Brazil (Pisces, Characiformes, Curimatidae). Cytologia 62:241-247.

Nelson JS (1994) Fishes of the World. 3rd ed. John Wiley and Sons, Inc., New York, 600 pp.

Oliveira C, Almeida-Toledo LF, Foresti F, Britski HA and Toledo- Filho SA (1988) Chromosome formulae of Neotropical freshwater fishes. Rev Bras Genet 11:577-624.

Oliveira C and Foresti F (1993) Occurrence of supernumerary microchromosomes in Steindachnerina insculpta (Pisces, Characiformes, Curimatidae). Cytobios 76:183-186.

Pauls E and Bertollo LAC (1983) Evidence for a system of supernumerary chromosomes in Prochilodus scrofa Steindachner, 1881 (Pisces, Prochilodontidae). Caryologia 36:307314.

Pauls E and Bertollo LAC (1990) Distribution of a supernumerary chromosome system and aspects of karyotypic evolution in the genus Prochilodus (Pisces, Prochilodontidae). Genetica 81:117-123.

Scheel JJ (1973) Fish chromosomes and their evolution. In: Internal Report of Danmartes Akvarvum. Charlotherlund, Denmark, pp 22.

Stange ER and Almeida-Toledo LF (1993) Supernumerary B chromosomes restricted to males in Astyanax scabripinnis (Pisces, Characidae). Rev Bras Genet 16:601-15.

Sumner AT (1972) A simple technique for demonstrating centromeric heterochromatin. Exp Cell Res 75:304-306.

Venere PC and Galetti PM (1985) Natural triploidy and chromosome B in the fish Curimata modesta (Curimatidae, Characiformes). Rev Bras Genet 8:681-687.

Venere PC and Galetti PM (1989) Chromosome evolution and phylogenetic relationships of some Neotropical Characiformes of the family Curimatidae. Rev Bras Genet 12:17-25.

Venere PC, Miyazawa C and Galetti PM (1999) New cases of supernumerary chromosomes in characiform fishes. Genet Mol Biol 22:345-349.

Associate Editor: Luiz Antonio Carlos Bertollo

License information: This is an open-access article distributed under the terms of the Creative Commons Attribution License, which permits unrestricted use, distribution, and reproduction in any medium, provided the original work is properly cited. 